\title{
Secondary Amiloidosis and Familial Mediterranean Fever Mimicking Recurrent Abdominal Sickling Crisis in a Patient with Sickle Cell Anemia
}

\author{
Orak Hücre Anemili Bir Hastada Tekrarlayan Karın Ağrısı Krizini Taklit Eden \\ Ailesel Akdeniz Ateşi ve Sekonder Amiloidozis
}

\author{
Kenan TURGUTALP, ${ }^{1}$ Ahmet KIYKIM, ${ }_{1}^{1}$ Feray TABAKAN, ${ }^{1}$ Anıl TOMBAK, ${ }^{2}$ Naci TİFTIK, ${ }^{2}$ Onur ÖZHAN ${ }^{3}$ \\ ${ }^{1}$ Department of Internal Medicine, Medical Faculty of Mersin University, Division of Nephrology, Mersin, Turkey \\ ${ }^{2}$ Department of Internal Medicine, Medical Faculty of Mersin University, Division of Hematology, Mersin, Turkey \\ ${ }^{3}$ Department of Internal Medicine, Medical Faculty of Mersin University, Division of Endocrinology, Mersin, Turkey
}

Familial Mediterranean fever (FMF) is characterized by recurrent polyserositis attacks. ${ }^{[1]}$ Its significiant clinical complication is secondary amyloidosis, and the M694V gene mutation, which is related to amyloidosis, is frequently seen. However, in Turkey, the heterozygote E148Q gene mutation is more common. ${ }^{[2]}$

Herein, we report a case involving the coexistence of beta thalassemia minor, renal amyloidosis and FMF with the E148Q heterozygous mutation in a 46-yearold male patient with sickle cell anemia (SCA) whose abdominal pains had been attributed to sickling crisis for almost 25 years.

This patient was admitted to our emergency department with complaints of general pain. His symptoms included joint and abdominal pain which occurred once or twice a month and lasted for twothree days. The patient had been hospitalized and treated many times at various centers due to his chronic, recurrent abdominal pain. Both superficial and deep palpations of the abdomen revealed widespread sensibility and defense, and generalized type edema was present as well. Laboratory tests revealed the following: hemoglobin $(\mathrm{Hb}) 6 \mathrm{~g} / \mathrm{dl}$, creatinine $1.9 \mathrm{mg} / \mathrm{dl}$, serum albumin $1.6 \mathrm{gr} / \mathrm{dl}$, HbS 79.9\%, $\mathrm{HbF} 4.9 \%$, $\mathrm{HbA} 8.5 \%$, and $\mathrm{HbA} 26.7 \%$. In addition, the patient's plasma fibrinogen level was $481 \mathrm{mg} / \mathrm{dl}$ (reference value: $170-400 \mathrm{mg} / \mathrm{dl}$ ), the serum amyloid level was $27.78 \mathrm{mg} / \mathrm{l}$ (reference value: 0-6.4 mg/l), the erythrocyte sedimentation rate (ESR) was $92 \mathrm{~mm} / \mathrm{h}$, and the C-reactive protein (CRP) level was $128 \mathrm{mg} / \mathrm{L}$. A 24-hour urine sample showed $7 \mathrm{gr} /$ day proteinuria, and there was no sediment activity in the spot urine sampling. Because of the presence of renal failure and nephrotic syndrome, the patient was hospitalized and underwent a renal biopsy, which detected secondary amyloidosis. Furthermore, FMF with the heterozygous E148Q gene mutation was also found in our patient. In fact, the patient fulfilled three major and eight minor Tel Hashomer criteria for FMF.

To the best of our knowledge, this is the first case report that involves the coexistence of SCA and beta thalassemia minor accompanied by amyloidosis secondary to FMF with the heterozygote E148Q mutation. Abdominal pain in patients with SCA can resemble acute abdomen. Pain crises in patients with SCA may present with severe abdominal sensitivity and/or rigidity, which makes it difficult to distinguish 
it from acute abdomen. Unfortunately, this sometimes leads to a misdiagnosis and large numbers of patients who undergo unnecessary surgery. ${ }^{[3]}$

Familial Mediterranean fever is one of the leading causes of secondary amyloidosis in Turkey. However, renal amyloidosis in patients with SCA is very rare in Turkey and has been reported primarily in case studies. In fact, only four cases of renal amyloidosis in patients with SCA have been documented in the literature..$^{[4-6]}$

The E148Q gene mutation is commonly associated with Mediterranean Fever (MEFV) in Turkey, ${ }^{[2]}$ and in more than half of the cases, it is homozygous. The most prominent clinical aspects of patients with the E148Q gene mutation are abdominal pain and fever. ${ }^{[2]}$ In contrast, our case had the heterozygous E148Q gene mutation with these same symptoms.

In conclusion, when physicians encounter patients with sickling crisis, they should consider a concurrent diagnosis of FMF, Particularly for patients living on the Mediterranean coast, recurrent abdominal pain and fever should be assessed since these symptoms are frequently associated with FMF in this region. In so doing, it may help prevent future cases with the complication of amyloid nephropathy in patients with FMF.

\section{Declaration of conflicting interests}

The authors declared no conflicts of interest with respect to the authorship and/or publication of this article.

\section{Funding}

The authors received no financial support for the research and/or authorship of this article.

\section{REFERENCES}

1. Shohat M, Halpern GJ. Familial Mediterranean fever--a review. Genet Med 2011;13:487-98.

2. Topaloglu R, Ozaltin F, Yilmaz E, Ozen S, Balci B, Besbas $\mathrm{N}$, et al. E148Q is a disease-causing MEFV mutation: a phenotypic evaluation in patients with familial Mediterranean fever. Ann Rheum Dis 2005;64:750-2.

3. Ahmed S, Shahid RK, Russo LA. Unusual causes of abdominal pain: sickle cell anemia. Best Pract Res Clin Gastroenterol 2005;19:297-310.

4. Hadj Sadek B, Radoui A, Al Hamany Z, Benamar L, Bayahia R, Ouzeddoun N. Renal amyloidosis: uncommon complication of sickle cell disease. Med Trop (Mars) 2011;71:185-6. [Abstract]

5. Akar H, Keven K, Nergizoglu G, Erturk S, Ates K, Erbay $\mathrm{B}$, et al. Renal amyloidosis in a patient with homozygous sickle cell anemia and M694V/M694V mutation. Nephron 2000;86:383-4.

6. Balal M, Paydas S, Seyrek N, Karayaylali I. Different glomerular pathologies in sickle cell anemia. Clin Nephrol 2004;62:400-1. 